\title{
Sistem Informasi Geografi untuk Simulasi Rute Penerbangan Virtual
}

\author{
Fahrul Agus $^{1 *}$, Dedy Fuadi², Yunizar Fahmi Badron ${ }^{3}$ \\ 1,2,3 Fakultas Ilmu Komputer dan Teknologi Informasi, Universitas Mulawarman \\ ${ }^{1,2,3} \mathrm{Jl}$. Barong Tongkok Kampus Gunung Kelua Telp. (0541) 741118, Kode Pos 75123, Samarinda-Indonesia \\ *Email Korespondensi: fahrulagus@unmul.ac.id
}

Dikirim 23 November 2016, Direvisi 7 Januari 2017, Diterima 14 Januari 2017

\begin{abstract}
Abstrak - Pilot penerbangan virtual menggunakan rute berbasis peta untuk mengoperasikan pesawat virtualnya. Untuk itu, diperlukan sistem yang mampu melakukan analisis rute yang mesti diambil oleh seorang penerbang virtual. Studi ini bertujuan membuat Sistem Informasi Geografi untuk simulasi rute penerbangan virtual menggunakan teknik pemrograman dinamis mundur (Backward Dynamic Programming-BDP). Teknik BDP dipilih karena kemampuannya melakukan analisis untuk optimasi rute terutama pada jenis penerbangan VFR (Visual Flight Rules) dengan rute berbentuk multistage graph. Studi ini menghasilkan deskripsi sistem simulasi rute penerbangan virtual berupa antarmuka program, pencarian rute penerbangan, dan hasil pengujian sistem.
\end{abstract}

Kata kunci - Backward Dynamic Programming, Penerbangan Virtual, Visual Flight Rules

Abstract - Pilot virtual flight using a map-based routing to operate the virtual plane. It required a system that can perform routing analysis which must be taken by virtual pilot. This study aims to create a geographic information system for routing virtual flight simulation using backward dynamic programming techniques. This technique chosen for its ability to optimize routing analysis, especially on the type of Visual Flight Rules with flight route shaped multistage graph. This research resulted in the description of the virtual flight simulation systems include a user interface, search flight routing, and system test result.

Keywords - Backward Dynamic Programming, Virtual Flight, Visual Flight Rules

\section{PENDAHULUAN}

Saat ini tersedia beberapa perangkat lunak yang berorientasi sebagai alat latih bagi pilot peerbangan sebelum ia terjun langsung pada pesawat yang sesungguhnya. Salah satu produk perangkat lunak simulator penerbangan saat ini yakni Microsoft Flight Simulator X. Namun, keberadaan alat simulasi tersebut sangat melekat kepada pengembangnya sebagai perangkat lunak berbayar. Kondisi ini memotivasi para pengembang perangkat lunak yang bergerak dalam bidang free and open source software untuk membangun program aplikasi yang mampu mensimulasikan sistem navigasi penerbangan dalam dunia virtual.

Sistem navigasi yang diterapkan oleh dunia penerbangan merupakan hasil adopsi dari sistem navigasi pelayaran saat mengarungi samudra maupun wilayah perairan tertentu [1]. Tidak berbeda jauh dengan perkembangan navigasi penerbangan, pelatihan yang diberikan kepada pilot pun semakin maju dengan memanfaatkan berbagai alat yang dapat merepresentasikan keadaan yang sebenarnya jika kelak calon pilot telah menjadi pilot yang sesungguhnya.

Seiring dengan perkembangan tersebut, ditambah lagi dengan kemunculan berbagai jenis game simulasi pesawat, hadir pula komunitas pengguna simulasi pesawat dan tergabung dalam organisasi internasional yang bernama IVAO (International Virtual Aviation Organization). Organisasi ini merupakan wadah yang menaungi anggota yang memiliki hobi yang sama dalam hal dunia penerbangan virtual.

Seperti halnya dunia penerbangan yang nyata, seorang penerbang virtual juga memerlukan rute penerbangan dalam melakukan penerbangan virtualnya. Namun, karena kurangnya fasilitas sistem yang dapat menganalisis rute, menyebabkan beberaoa game simulasi penerbangan dirasa kurang optimal, 
terutama pada jenis penerbangan VFR (Virtual Flight Rules). Keadaan ini berlaku ketika pilot virtual melakukan navigasi udara, komunikasi radio, dan pemanfaatan navigasi lainnya pada sistem simulasinya.

Studi ini menggunakan navigasi radio sebagai kunci dalam pencarian rute penerbangan. Metode yang digunakan untuk mencapai hasil yang optimal dalam pencarian rute yakni dengan menerapkan teknik BDP. Hal ini dikarenakan adanya prinsip optimasi pada metode yang diterapkan. Selain menghasilkan hasil akhir optimal, metode ini dipilih karena pemrograman dinamis cocok dengan tipe masalah yang berbentuk multistage graph. Rute yang digunakan diilustrasikan sebagai suatu wilayah navigasi radio dengan lapisan jangkauan frekuensi navigasi radio yang mencerminkan lokasi bandara penerbangan.

\section{METODE PENELITIAN}

\section{A. Studi Referensi}

Sistem Informasi Geografi (SIG) adalah sistem yang berbasiskan komputer yang digunakan untuk menyimpan dan memanipulasi informasi geografis. Sistem ini dirancang untuk mengumpulkan, menyimpan, dan menganalisis objek-objek dan fenomena dimana lokasi geografis merupakan karakteristik yang penting atau kritis untuk dianalisis. Dengan demikian, SIG merupakan sistem computer yang memiliki empat kemampuan berikut dalam menangani data yang bereferensi geografis. [2]

a) Masukan;

b) Manajemen data (penyimpanan dan pemanggilan data);

c) Analisis dan manipulasi data; dan

d) Keluaran

Beberapa penelitian berbasis grafis dan bersifat memberikan layanan informasi lokasi antara lain pengembangan sistem layanan berbasis lokasi Location Based Services [3], [4]. Sistem ini memberikan data lokasi pengguna serta informasi lokasi-lokasilayanan terdekat antara lain rumah sakit, ATM, obyek wisata, dan layanan lainnya. Penelitian lain yang berbasis lokasi yakni dikerjakan oleh Pandhita A.L. dan Yuliansyah H. Dengan membuat aplikasi untuk menentukan titik lokasi Distribution Point PT. Telkom Indonesia Kandatel Pati Jawa Tengah [5]. Penelitian ini berhasil mengimplementasikan konsep SIG pada layanan penentuan lokasi geografis suatu wilayah.

\section{B. Peraturan VFR Semicircular Cruise Altitude}

Tabel berikut menjelaskan rute pada jenis penerbangan VFR dan menjadi acuan pada simulasi penerbangan virtual [5].
Tabel 1. Tabel Normal Semicircular Cruise Altitude

\begin{tabular}{|c|c|c|c|c|c|}
\hline \multicolumn{6}{|c|}{ VFR Flight } \\
\hline \multicolumn{3}{|c|}{ Track from $0^{\circ}$ to $179^{\circ}$} & \multicolumn{3}{|c|}{ Track from $180^{\circ}$ to $359^{\circ}$} \\
\hline$F L$ & Feet & Meter & $F L$ & Feet & Meter \\
\hline 35 & 3500 & 1050 & 45 & 4500 & 1350 \\
\hline 55 & 5500 & 1700 & 65 & 6500 & 2000 \\
\hline 75 & 7500 & 2300 & 85 & 8500 & 2600 \\
\hline 95 & 9500 & 2900 & 105 & 10500 & 3200 \\
\hline 115 & 11500 & 3500 & 125 & 12500 & 3800 \\
\hline 135 & 13500 & 4100 & 145 & 14500 & 4400 \\
\hline 155 & 15500 & 4700 & 165 & 16500 & 5050 \\
\hline 175 & 17500 & 5350 & 185 & 18500 & 5650 \\
\hline 195 & 19500 & 5950 & 205 & 20500 & 6250 \\
\hline 215 & 21500 & 6550 & 225 & 22500 & 6850 \\
\hline 235 & 23500 & 7150 & 245 & 24500 & 7450 \\
\hline 255 & 25500 & 7750 & 265 & 26500 & 8100 \\
\hline 275 & 27500 & 8400 & 285 & 28500 & 8700 \\
\hline
\end{tabular}

C. Spherical Law of Cosine

Untuk menghitung jarak antara dua buah titik korrdinat di permukaan bumi, diperlukan sebuah metode yang sebelumnya harus diketahui dahulu jarijari bumi yang disetujui oleh para ahli. Agar tercipta suatu paham yang sama untuk pengukuran ini, maka para ahli menggunakan pola pikir bahwa bumi berbentuk seperti bola sehingga jari-jari yang diambil dari beberapa perhitungan sebelumnya adalah jari-jari rataan untuk permukaan bumi. Dalam mencari jarak antara dua buah koordinat di permukaan bumi, digunakanlah rumus sebagai berikut. [7]

$$
d=\operatorname{acos}\left(\sin \left({ }_{1}\right) \cdot \sin \left({ }_{2}\right)+\cos \left({ }_{1}\right) \cdot \cos \left({ }_{2}\right) \cdot \cos (\Delta \lambda)\right) \cdot R
$$

Dimana $\varphi$ adalah latitude, $\lambda$ adalah longitude, $\mathrm{R}$ adalah radius bumi (jari-jari rataan $=6371 \mathrm{~km}$ ).

\section{Backward Dynamic Programming - BDP}

Teknik BDP merupakan metode pemecahan dengan cara menguraikan masalah solusi menjadi sekumpulan langkah (step) atau tahapan (stage) sedemikian sehingga solusi dari persoalan dapat dipandang dari serangkaian keputusan yang saling berkaitan [8].

Pada program dinamis, rangkaian keputusan yang optimal dibuat dengan menggunakan prinsip optimasi. Prinsip optimasi adalah solusi total optimal, maka bagian solusi sampai tahap ke-k juga optimal. Prinsip optimasi berarti bahwa jika pengguna bekerja dari tahap $\mathrm{k}$ ke tahap $\mathrm{k}+1$, pengguna dapat menggunakan hasil optimal dari tahap $\mathrm{k}$ tanpa harus kembali ke tahap awal.

Dengan prinsip optimasi ini dijamin bahwa pengambilan keputusan pada suatu tahap adalah keputusan yang benar untuk tahap-tahap selanjutnya.

Karakteristik persoalan program dinamis. 
a) Persoalan dapat dibagi menjadi beberapa tahap (stage) yang pada setiap tahap hanya diambil satu keputusan

b) Masing-masing tahap terdiri dari ejumlah status (state) yang berhubungan dengan tahap tersebut. Graf multitahap (multistage graph), tiap simpul di dalam graf tersebut menyatakan status, sedangkan $\mathrm{V}_{1}, \mathrm{~V}_{2}, \ldots$ menyatakan tahap.

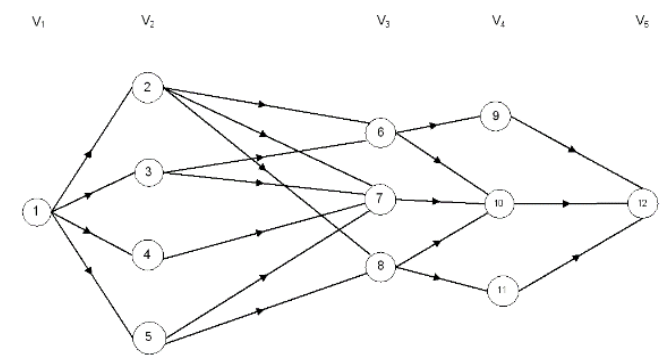

Gambar 1. Graf Yang Menyatakan Tahap (Stage) Dan Status (State)

c) Hasil dari keputusan yang diambil pada setiap tahap ditransformasikan dari status yang bersangkutan ke status berikutnya pada tahap berikutnya.

d) Ongkos (cost) pada suatu tahap meningkat secara teratur (steadily) dengan bertambahnya jumlah tahapan.

e) Ongkos pada sutau tahap bergantung pada ongkos tahap-tahap yang sudah berjalan dan ongkos pada tahap tersebut.

f) Keputusan terbaik pada suatu tahap bersifat independen terhadap keputusan yang dilakukan pada tahap sebelumnya.

g) Adanya hubungan rekursif yang mengidentifikasikan keputusan terbaik untuk setiap status pada tahap $\mathrm{k}$ memberikan keputusan terbaik untuk setiap status pada tahap $\mathrm{k}+1$.

h) Prinsip optimasi berlaku pada persoalan tersebut.

Dua pendekatan yang digunakan dalam BDP, yaitu maju (forward atau up-down) dan mundur (backward atau bottom-up). Misalkan $\mathrm{x}_{1}, \mathrm{x}_{2}, \ldots, \mathrm{x}_{\mathrm{n}}$ menyatakan peubah (variable) keputusan yang harus dibuat masing-masing untuk tahap $1,2, \ldots, n$. Maka.

a) Program dinamis maju. Program dinamis bergerak mulai dari tahap 1, terus maju ke tahap 2, 3, dan seterusnya sampai tahap $\mathrm{n}$. Runtunan peubah keputusan adalah $\mathrm{x}_{1}, \mathrm{x}_{2}, \ldots$, $x_{n}$.

b) Program dinamis mundur. Program dinamis bergerak mulai dari tahap $n$, terus mundur ke tahap $\mathrm{n}-1, \mathrm{n}-2$, dan seterusnya sampai tahap 1. Runtunan peubah kputusan adalah $\mathrm{x}_{\mathrm{n}}, \mathrm{x}_{\mathrm{n}-1}$, ..., $\mathrm{x}_{1}$.

\section{E. Quantum GIS}

Salah satu paket aplikasi pengolahan Sistem Informasi Geografi yang bersifat free and open source adalah Quantum GIS. Paket ini mencakup pemetaan, analisis spasial, dan beberapa fitur desktop GIS lainnya. Aplikasi ini sama dengan paket aplikasi GIS komersial, tetapi aplikasi didistribusikan secara gratis di bawah lisensi GNU. Quantum GIS mendukung format data vector, raster, dan database (PostGIS dan Oracle). Quantum GIS juga dapat deprogram ulang untuk mengerjakan tugas yang berbeda atau lebih spesifik. Aplikasi ini juga merupakan suatu aplikasi multi-platform yang dapat dijalankan pada sistem operasi berbeda-beda, termasuk MacOS X, Linux, Unix, dan Windows XP [9]. Pada penelitian ini, Quantum GIS digunakan untuk mengolah data peta untuk lokasi penerbangan.

\section{F. Metode Penelitian}

Ilustrasi tahap studi ini didasarkan pada penentuan rute penerbangan dari titik $A$ ke titik $B$ sebagai berikut.

a) Dilakukan pencarian koordinat titik A (origin airport) dan titik B (destination airport). Pengaksesan database untuk memperoleh data yang diinginkan.

b) Hitung jarak langsung (garis lurus) dari ririk A ke titik B. Diterapkan rumus "Spherical Law of Cosine".

c) Dihitung besar azimuth dari kedua bandara guna keperluan penerapan semi-circular cruise altitude.

d) Penentuan cara penerbangan, apakah terbang langsung menuju bandara tujuan atau diharuskan melalui bandara penghubung.

e) Jumlah layer yang akan digunakan untuk perhitungan metode pemrograman dinamis mundur ditentukan melalui perhitungan sistem yakni berdasarkan jarak kedua bandara dengan jarak tiap layer-nya kurang lebih sejauh 150 $\mathrm{nm}$.

f) Ruang navigasi dipersempit dengan cara dibentuk lingkaran maya dengan radius jarak A ke B sebagai diameter lingkaran.

g) Anggota (bandara/titik navigasi) yang terlibat dalam ruang/wilayah navigasi berbentuk lingkaran ditentukan dengan cara mengeliminasi bandara yang jaraknya lebih besar dari jari-jari lingkaran navigasi berdasarkan titik pusat lingkaran.

h) Titik-titik pembagi pada garis azimuth utama yang merupakan titik perpotongan antara azimuth utama dengan tiap batas layr dicari sebagai salah satu referensi guna penerapan teori persamaan garis lurus.

i) Pemanfaatan teori persamaan garis lurus guna membangun batas wilayah lapis navigasi berupa lapisan-lapisan yang arah garisnya 
tegak lurus $\left(90^{\circ}\right)$ terhadap azimuth utama dari kedua bandara. Dalam hal ini, gradien masingmasing garis ditentukan dan dirancang pula persamaan garis lurus tiap garisnya baik berorientasi pada sumbu x maupun $\mathrm{y}$.

j) Anggota tiap layer/lapis navigasi ditentukan dengan cara menguji tiap koordinat bandara pada ruang lingkar navigasi terhadap tiap persamaan garis lurus yang telah ditentukan.

k) Pemilihan rute terbaik dengan penerapan metode pemrograman dinamis mundur.

1) Azimuth tiap garis penghubung/rute yang menghubungkan masing-masing titik pada rute yang akan dilewati ditentukan dengan menggunakan trigonometri.

\section{HASIL PENELITIAN}

\section{A. Implementasi Antarmuka Pengunjung}

Antarmuka pengunjung terbagi menjadi dua buah halaman yang berbeda, yaitu halaman awal (Gambar 2) dan halaman navigasi peta dinamis (Gambar 3). Hal ini dikarenakan tujuan sistem adalah untuk pencarian rute penerbangan, sedangkan untuk navigasi peta dinamis merupakan fasilitas tambahan bagi pengunjung website jika ingin mencari data spasial yang tersedia.

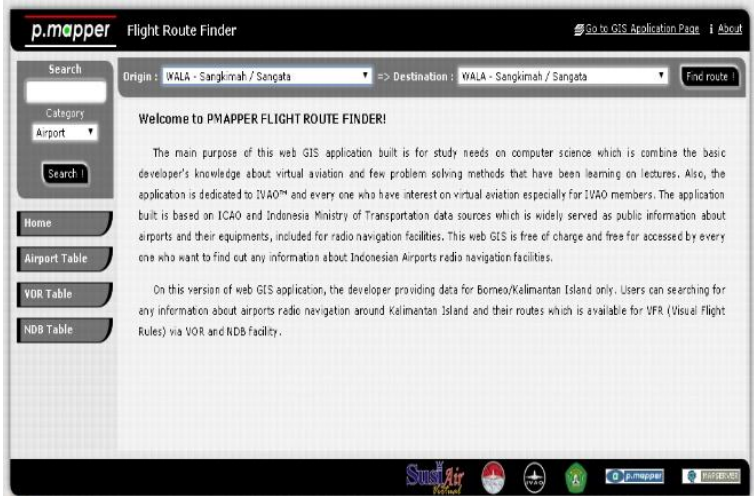

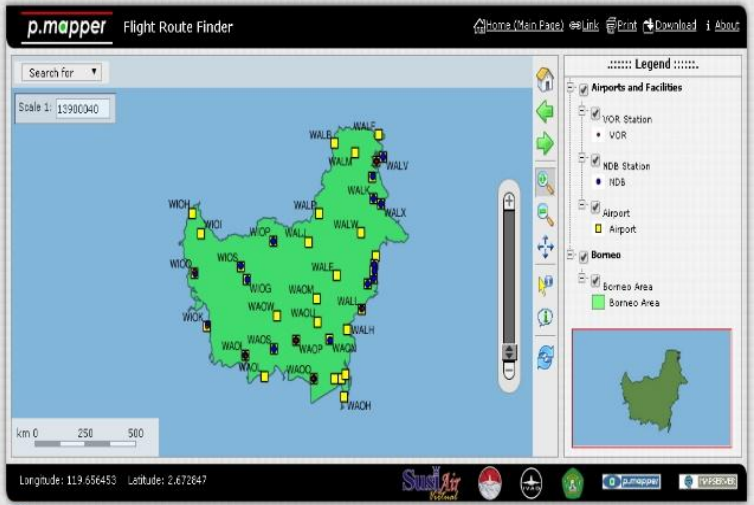

Gambar 3. Halaman Navigasi Peta Dinamis

\section{B. Implementasi Sistem Pencarian Rute Langsung}

Jika sistem memutuskan bahwa jenis rute yang dieksekusi adalah jenis rute langsung (direct route) atau terbang tanpa melalui bandara penghubung, maka sistem tidak akan mengikutsertakan metode pemrograman dinamis mundur dalam penyelesaian rute tersebut, Karena hanya ada dua buah bandara yang terlibat dalam rute ini, yaitu bandara awal (origin) dan bandara tujuan (destination).

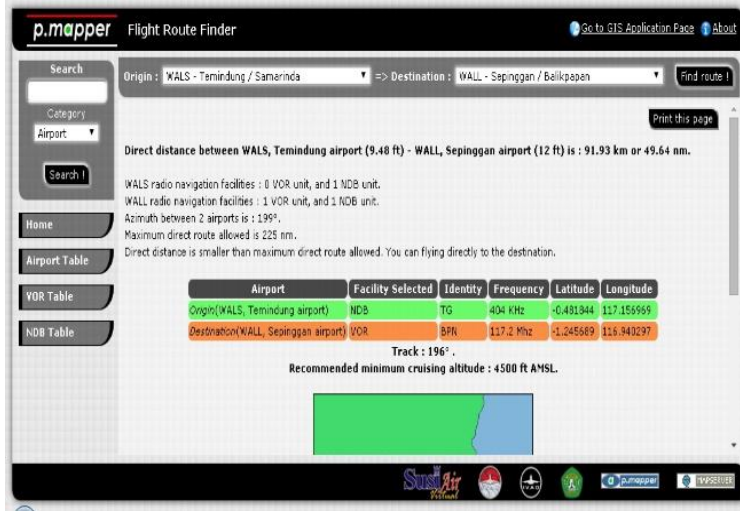

Gambar 4. Jenis Rute Langsung

Gambar 2. Halaman Awal

Tabel 2. Rute Terpilih Jenis Rute Langsung

\begin{tabular}{cccccc}
\hline Airport & $\begin{array}{c}\text { Facility } \\
\text { Selected }\end{array}$ & Identity & Frequency & Latitude & Longitude \\
\hline $\begin{array}{c}\text { Origin (WALS, } \\
\text { Temindung } \text { airport) } \\
\begin{array}{c}\text { Destination (WALL, } \\
\text { Sepinggan airport) }\end{array}\end{array}$ & NDB & TG & $404 \mathrm{KHz}$ & -0.481844 & 117.156969 \\
\hline & & BPN & $117.2 \mathrm{Mhz}$ & -1.245689 & 116.940297 \\
\hline
\end{tabular}

Recommended minimum cruising altitude : $4500 \mathrm{ft}$ AMSL.

Dari contoh rute langsung yang telah dipilih oleh penulis, dengan Bandara Temindung sebagai bandara awal dan Bandara Sepinggan sebagai bandara tujuan, diperoleh jenis rute yang merupakan rute langsung. Hal ini dikarenakan jarak langsung dari Temindung ke Sepinggan (49.64 nm) lebih kecil daripada batas jarak rute langsung yang diizinkan oleh sistem (225 nm). Track menunjukkan arah jalur penerbangan yang harus diikuti oleh pilot virtual adalah pada arah $196^{\circ}$ dengan mengikuti dan menyetel frekuensi radio untuk TG NDB (404 KHz) dan BPN VOR (117.2 MHz). Cruising altitude menunjukkan ketinggian jelajah terbang pada rute ini yaitu $4500 \mathrm{ft}$ (kaki) di atas permukaan air laut. Dipilih 4500 karena arah terbang kea rah barat atau dinamakan westbound. 


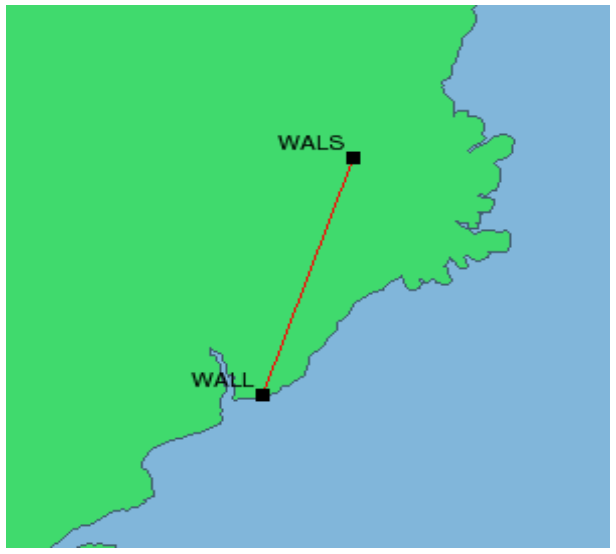

Gambar 5. Hasil Keluaran Peta Digital Rute Langsung beberapa bandara penghubung yang harus diputuskan sebagai rute terpendek.

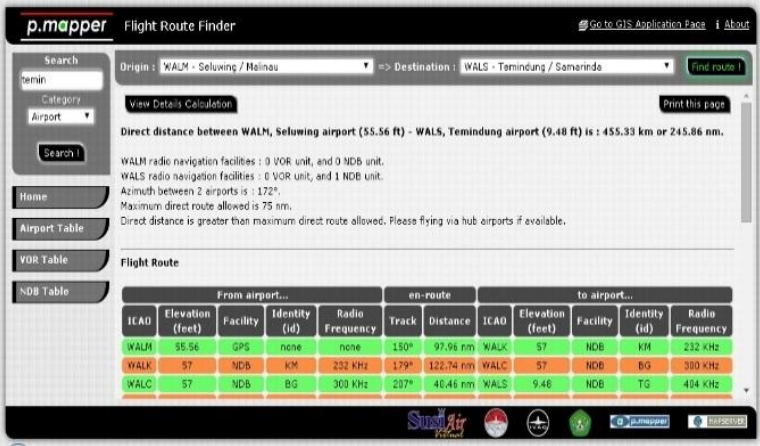

Gambar 6. Jenis Rute Bandara Penghubung

C. Implementasi Sistem Pencarian Rute Bandara Penghubung

Pada rute jenis ini, keputusan untuk penentuan rute dilakukan dengan cara melibatkan metode pemrograman dinamis mundur karena terdapat

Tabel 3. Hasil Metode Pemrograman Dinamis Mundur

\begin{tabular}{ccccccc}
\hline \multicolumn{3}{c}{ Airport and Station } & \multicolumn{2}{c}{ en-route } \\
\hline ICAO & $\begin{array}{c}\text { Elevation } \\
(\text { feet })\end{array}$ & Facility & Identity (id) & Radio Frequency & Track & Distance (nm) \\
\hline WALM & 55.56 & GPS & none & none & $150^{\circ}$ & 97.96 \\
WALK & 57 & NDB & KM & $232 \mathrm{KHz}$ & $179^{\circ}$ & 122.74 \\
WALC & 57 & NDB & BG & $300 \mathrm{KHz}$ & $207^{\circ}$ & 40.46 \\
WALS & 9.48 & NDB & TG & $404 \mathrm{KHz}$ & & \\
\hline
\end{tabular}

Flight path for this route:

(Origin) WALM $=>$ WALK $=>$ WALC $=>$ WALS(Destination) Route distance $: 261.15 \mathrm{~nm}$ Recommended cruising altitude $: 3500 \mathrm{ft}$ AMSL

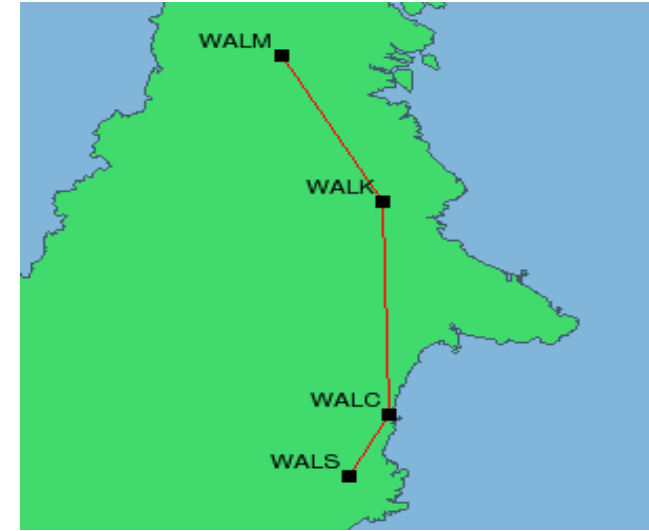

Gambar 7. Hasil Keluaran Peta Digital Rute Bandara Penghubung

\section{PEMBAHASAN}

Pada tahap ini diharapkan dapat menemukan kesimpulan guna melihat kemampuan sistem dalam memecahkan masalah, yaitu dalam hal mencari rute terpendek dengan memanfaatkan metode pencarian rute terpendek yang dalam hal ini digunakan metode pemrograman dinamis mundur, serta digabungkan dengan aturan penerbangan VFR dalam dunia simulasi pesawat yang mengadopsi aturan dari dunia penerbangan yang sesungguhnya.

Untuk mencapai hasil tersebut, dibuat sebuah fungsi tambahan yang digunakan sebagai penguji sistem untuk melihat kemampuan dalam menyelesaikan masalah. Pengujian ini juga dilakukan guna penyesuaian dan seleksi jarak antar layer yang dapat menghasilkan hasil terbaik, baik dalam hal persentase penerapan metode serta kecocokan terhadap aturan penerbangan VFR.

Pengujian dilakukan terhadap 741 garis (jalur) yang merupakan jumlah total garis yang terdapat pada tabel line_geo, yang juga merupakan hasil perhitungan kombinasi probabilitas dari tiap bandara yang ada. Tiap tahap pengujian mewakili 741 jalur yang akan diuji terhadap empat variasi jarak layer. Variasi jarak layer didapat dari aturan penerbangan VFR yang mengharuskan.

a) Jangkauan maksimal 1 buah NDB adalah 75 $\mathrm{nm}$; dan

b) Jangkauan maksimal 1 buah VOR adalah 150 $\mathrm{nm}$. 
Empat kondisi akan disertakan dalam pengujian ini, yaitu.

a) Jarak $75 \mathrm{~nm}$

Kondisi ini diasumsikan bahwa pada dua buah bandara, hanya terdapat sebuah NDB pada salah satu bandara.

b) Jarak $150 \mathrm{~nm}$

Kondisi ini diasumsikan bahwa pada dua buah bandara.

1. Hanya terdapat sebuah VOR pada salah satu bandara; atau

2. Terdapat sebuah NDB pada masing-masing bandara.

c) Jarak $225 \mathrm{~nm}$

Kondisi ini diasumsikan bahwa pada dua buah bandara, salah satu bandara memiliki sebuah VOR dan lainnya memiliki sebuah NDB.

d) Jarak $300 \mathrm{~nm}$

Kondisi ini diasumsikan bahwa pada dua buah bandara memiliki masing-masing sebuah VOR.

Dikarenakan jumlah garis yang terlalu banyak (741 rute), maka dalam penelitian ini hanya disertakan hasil perhitungannya saja sebagai berikut.

a) Kombinasi probabilitas bandara

Dalam mencari kemungkinan yang muncul pada permasalahan peluang kombinasi secara statistic, maka diperlukan persamaan sebagai berikut [10].

$$
C_{n}^{k}=\frac{n !}{(n-k) ! k !}
$$

Keterangan

$\mathrm{C}$ : notasi kombinasi

$\mathrm{k}$ : angka kombinasi yang diinginkan

$\mathrm{n}:$ jumlah data

$C_{39}^{2}=\frac{39 !}{(39-2) ! \cdot 2 !}=\frac{39 !}{37 ! \cdot 2 !}=\frac{39 \cdot 38 \cdot 37 !}{37 ! \cdot 2 \cdot 1}=\frac{1482}{2}=741$

Angka kombinasi dipilih angka 2, Karena tiap rute mewakili sebuah bandara awal dan sebuah bandara tujuan, sedangkan jumlah data bandara yang tersedia adalah sebanyak 39 bandara.

b) Perhitungan persentase

Di sini akan dihitung.

1. Rute yang menggunakan BDP (backward dynamic programming) atau pemrograman dinamis mundur dalam sistem (n).

Merupakan jumlah dari jenis rute bandara penghubung (penerbangan melalui bandara penghubung guna menciptakan sebuah rute).

2. Pertambahan jarak yang dihasilkan dari BDP (p1)
Persentase ini didapat dari hasil pengurangan antara jarak rute dikurangi jarak langsung.

$$
p 1=\frac{j r-j l}{j l} \cdot 100 \%
$$

Keterangan.

p1 : persentase pertambahan jarak

jr : jarak rute

jl : jarak langsung

3. Rataan pertambahan jarak $(\overline{p 1})$

Persentase ini didapat dari nilai rata-rata pertambahan jarak semua rute bandara penghubung.

$$
\overline{p 1}=\frac{\sum_{n}^{1} p 1}{n}
$$

Keterangan.

$\overline{p 1}$ : persentase rata-rata pertambahan jarak rute bandara penghubung

p1 : pertambahan jarak rute bandara penghubung

n : jumlah rute yang termasuk dalam jenis rute bandara penghubung

4. Kesuksesan penerapan BDP (bdps)

Persentase ini didapat dari jumlah rute bandara penghubung yang mengalami pertambahan jarak kurang dari atau sama dengan $20 \%$ dibagi dengan jumlah rute bandara penghubung.

$b d p s=\frac{b d p 20}{n} \cdot 100 \%$

Keterangan.

bdps : persentase kesuksesan penerapan BDP

bdp20: jumlah rute yang persentase pertambahan jaraknya kurang dari atau sama dengan $20 \%$

n : jumlah rute yang termasuk dalam jenis rute bandara penghubung

5. Kesuksesan koneksi radio navigasi (p2)

Persentase ini didapat dari kemampuan jarak total yang seharusnya dapat dijangkau oleh frekuensi radio navigasi pada masingmasing rute bandara penghubung dibagi dengan jarak rute bandara penghubung tersebut.

$p 2=\frac{j r n}{j r} \cdot 100 \%$

Keterangan.

p2 : persentase kesuksesan koneksi radio navigasi

jrn : jarak total jangkauan radio navigasi

jr : jarak rute bandara penghubung 
6. Rataan kesuksesan koneksi radio navigasi

$$
\overline{p 2}=\frac{\sum_{n}^{1} p 2}{n}
$$

Keterangan.

$\overline{p 2}$ : rata-rata persentase kesuksesan koneksi radio navigasi

p2 : persentase kesuksesan koneksi radio navigasi

n : jumlah rute yang termasuk dalam jenis rute bandara penghubung

7. Kesuksesan akhir

Persentasi ini didapat dari penjumlahan antara hasil sisa persentase rataan pertambahan jarak ditambah dengan rataan persentase kesuksesan koneksi radio navigasi, lalu dibagi dua.

$$
\begin{aligned}
& \text { ps } 1=100 \%-\overline{p 1} \\
& p f=\frac{p s 1+\overline{p 2}}{2} \cdot 100 \%
\end{aligned}
$$

Keterangan.

$\overline{p 1}$ : persentase rata-rata pertambahan jarak rute bandara penghubung

ps1 : sisa persentase rataan pertambahan jarak

$\overline{p 2}$ : rata-rata persentase kesuksesan koneksi radio navigasi

pf : persentase kesuksesan akhir

\section{Jarak antar layer 75 nm}

$n=567$

$$
n \%=\frac{567}{741} \cdot 100 \%=76.52 \%
$$

Tabel 4. Tabel Peringkat Pertambahan Jarak Interval $75 \mathrm{~nm}$

\begin{tabular}{ccc}
\hline Peringkat & Persentase pertambahan jarak & Jumlah \\
\hline A & $<=20 \%$ & 391 \\
B & $21 \%-40 \%$ & 147 \\
C & $41 \%-60 \%$ & 24 \\
D & $61 \%-80 \%$ & 2 \\
E & $>=81 \%$ & 3 \\
\hline
\end{tabular}

Rata-rata persentase pertambahan jarak.

$\overline{p 1}=\frac{16451.47062 \%}{567}=29.01 \%$

Persentase kesuksesan penerapan BDP.

bdps $=\frac{267}{567} \cdot 100 \%=47.09 \%$

Persentase kesuksesan koneksi radio navigasi.

$\overline{p 2}=\frac{50886.5275 \%}{567}=89.75 \%$

Persentase kesuksesan akhir

$$
p f=\frac{(100-29.01494) \%+89.74696 \%}{2}=80.37 \%
$$

\section{Jarak antar layer $150 \mathrm{~nm}$}

$$
\begin{aligned}
& n=567 \\
& n \%=\frac{567}{741} \cdot 100 \%=76.52 \% \\
& \quad \begin{array}{c}
\text { Tabel } 5 . \text { Tabel Peringkat Pertambahan } \\
\text { Jarak Interval } 150 \mathrm{~nm}
\end{array}
\end{aligned}
$$

\begin{tabular}{ccc}
\hline Peringkat & Persentase pertambahan jarak & Jumlah \\
\hline A & $<=20 \%$ & 267 \\
B & $21 \%-40 \%$ & 163 \\
C & $41 \%-60 \%$ & 68 \\
D & $61 \%-80 \%$ & 38 \\
E & $>=81 \%$ & 31 \\
\hline
\end{tabular}

Rata-rata persentase pertambahan jarak.

$\overline{p 1}=\frac{8797.29903 \%}{567}=15.52 \%$

Persentase kesuksesan penerapan BDP.

$$
b d p s=\frac{391}{567} \cdot 100 \%=68.96 \%
$$

Persentase kesuksesan koneksi radio navigasi.

$$
\overline{p 2}=\frac{49832.29455 \%}{567}=87.89
$$

Persentase kesuksesan akhir

$$
p f=\frac{(100-15.51555) \%+87.88765 \%}{2}=86.19 \%
$$

Jarak antar layer $225 \mathrm{~nm}$

$$
\begin{aligned}
& n=567 \\
& n \%=\frac{567}{741} \cdot 100 \%=76.52 \%
\end{aligned}
$$

Tabel 6. Tabel Peringkat Pertambahan Jarak Interval $225 \mathrm{~nm}$

\begin{tabular}{ccc}
\hline Peringkat & Persentase pertambahan jarak & Jumlah \\
\hline A & $<=20 \%$ & 494 \\
B & $21 \%-40 \%$ & 67 \\
C & $41 \%-60 \%$ & 4 \\
D & $61 \%-80 \%$ & 0 \\
E & $>=81 \%$ & 2 \\
\hline
\end{tabular}

Rata-rata persentase pertambahan jarak.

$$
\overline{p 1}=\frac{5393.70453 \%}{567}=9.51 \%
$$

Persentase kesuksesan penerapan BDP.

bdps $=\frac{494}{567} \cdot 100 \%=87.13 \%$

Persentase kesuksesan koneksi radio navigasi.

$\overline{p 2}=\frac{46337.68966 \%}{567}=81.72 \%$ 
Persentase kesuksesan akhir

$$
p f=\frac{(100-9.51271) \%+81.72432 \%}{2}=86.11 \%
$$

\section{Jarak antar layer 300 nm}

$$
\begin{gathered}
n=567 \\
n \%=\frac{567}{741} \cdot 100 \%=76.52 \% \\
\quad \begin{array}{c}
\text { Tabel } 7 . \text { Tabel Peringkat Pertambahan } \\
\text { Jarak Interval } 300 \mathrm{~nm}
\end{array}
\end{gathered}
$$

\begin{tabular}{ccc}
\hline Peringkat & Persentase pertambahan jarak & Jumlah \\
\hline A & $<=20 \%$ & 518 \\
B & $21 \%-40 \%$ & 48 \\
C & $41 \%-60 \%$ & 1 \\
D & $61 \%-80 \%$ & 0 \\
E & $>=81 \%$ & 0 \\
\hline
\end{tabular}

Rata-rata persentase pertambahan jarak.

$\overline{p 1}=\frac{3862.44655 \%}{567}=6.81 \%$

Persentase kesuksesan penerapan BDP.

$b d p s=\frac{518}{567} \cdot 100 \%=91.36 \%$

Persentase kesuksesan koneksi radio navigasi.

$\overline{p 2}=\frac{42962.53537 \%}{567}=75.77 \%$

Persentase kesuksesan akhir

$p f=\frac{(100-6.81208) \%+75.77167 \%}{2}=84.48 \%$

Berdasarkan hasil perhitungan dari masingmasing persentase, didapat hasil sebagai berikut:

Tabel 8. Tabel Rangkum Hasil Persentase

\begin{tabular}{cclcc}
\hline Interval & $\overline{p 1}$ & $b d p s$ & $\overline{p 2}$ & $p f$ \\
\hline $75 \mathrm{~nm}$ & $29.01 \%$ & $47.09 \%$ & $89.75 \%$ & $80.37 \%$ \\
$150 \mathrm{~nm}$ & $15.52 \%$ & $68.96 \%$ & $87.89 \%$ & $86.19 \%$ \\
$225 \mathrm{~nm}$ & $9.51 \%$ & $87.13 \%$ & $81.72 \%$ & $86.11 \%$ \\
$300 \mathrm{~nm}$ & $6.81 \%$ & $91.36 \%$ & $75.77 \%$ & $84.48 \%$ \\
\hline
\end{tabular}

Dari Tabel 8 dapat diambil keputusan bahwa interval jarak yang cocok dengan sistem dan kebutuhan rute adalah pada interval layer $150 \mathrm{~nm}$ dengan nilai persentase rata-rata pertambahan jarak sebesar $15.52 \%$, persentase kesuksesan penerapan pemrograman dinamis mundur sebesar $68.96 \%$, nilai rataan persentase kesuksesan koneksi fasilitas radio navigasi sebesar $87.89 \%$, dan persentase kesuksesan akhir mencapai $86.19 \%$ untuk kelompok rute yang dapat diselesaikan dengan menggunakan metode pemrograman dinamis mundur dalam sistem.

\section{PENUTUP}

\section{A. Kesimpulan}

a) Studi ini telah menerapkan teknik BDP dan aturan penerbangan VFR pada sistem simulasi penerbangan virtual.

b) Metode pemrograman dinamis mundur dapat digunakan untuk 567 rute bandara penghubung atau sebesar $76.52 \%$ dari jumlah seluruh rute yang dapat dikerjakan oleh sistem sebanyak 741 rute.

c) Interval yang sesuai untuk digunakan sebagai interval layer pada sistem adalah sebesar 150 $\mathrm{nm}$.

d) Metode pemrograman dinamis mundur yang diterapkan dalam sistem dapat menyelesaikan masalah pencarian rute penerbangan VFR dengan nilai kesuksesan akhir mencapai $86.19 \%$ dari seluruh 567 rute yang melalui bandara penghubung.

\section{B. Saran}

Penulis menyadari masih terdapat banyak kekurangan dalam penelitian ini. Oleh sebab itu, diusulkan beberapa saran sebagai berikut:

a) Simbol untuk tiap layer pada aplikasi web SIG (peta dinamis) serta peta digital hasil output pencarian rute perlu diberikan sedikit variasi bentuk agar menjadi pembeda antar satu layer dengan yang lain.

b) Pengelola sistem perlu memantau perkembangan bandara yang terdapat pada Pulau Kalimantan (Indonesia) untuk penyesuaian data agar tetap terbaharui.

c) Perlu ditambahkan menu atau bagian pada halaman website untuk meletakkan news/berita terbaru mengenai sistem maupun data terbaru yang tersedia.

\section{DAFTAR PUSTAKA}

[1] Taylor, Ron., Lambert, Mark., dan Tim Penerbit. 1983, Alam Pesawat, Gramedia, Jakarta.

[2] Aronoff, Stanley. 1989, Geographic Information System: A Management Perspective, WDL Publication, Otawa.

[3] Rosdania, Fahrul Agus, Awang Harsa. Sistem Informasi Geografi Batas Wilayah Kampus Universitas Mulawarman Menggunakan Google Maps API. Jurnal Informatika Mulawarman, Vol. 10 No. 1, Hal 38-46, ISSN: 1858-485. https://fmipa.unmul.ac.id/jurnal/detail/23. Februari 2015

[4] G. W. Sasmito dan F. Hadiansah, "Implementasi Location Based Service Rute Objek Wisata Tegal," J. INFOTEL, vol. 7, no. 2, pp. 107-112, 2015.

[5] A. L. Pandhita dan H. Yuliansyah, "Rancang Bangun Aplikasi Android Berbasis Lokasi Untuk Pencarian Distribution Point," J. INFOTEL, vol. 7, no. 2, pp. 8392, 2016. 
[6] IVAO Training Department Headquarters. 2014, VFR Cruise Altitude or Flight Level, Version 2.0., IVAOTM, Belgia.

[7] Vennes, Chris. 2012, Calculate distance and bearing between two Latitude/Longitude points using haversine formula in JavaScript, http://movabletype.co.uk/scripts/latlong.html, diakses 20 April 2014.

[8] Munir, Rinaldi. 2004, Bahan Kuliah ke-13 : Program Dinamis (Dynamic Programming), Departemen Teknik Informatika Institut Teknologi Bandung, Bandung.
[9] Ulfiah. 2010, Sistem Informasi Geografi Pendidikan kota Bogor berbasis Web dengan Menggunakan Quantum GIS, Jurnal Nasional, Universitas Gunadarma, Depok.

[10] Hifni. 1991. Metode Statistika. Malang : Kopma Unibraw. 